\title{
Self-assembled coordination thioether silver(I) macrocyclic complexes for homogeneous catalysis
}

\author{
Zhen Cao, Aline Lacoudre, Cybille Rossy and Brigitte Bibal ${ }^{*}$
}

\author{
Full Research Paper \\ Address: \\ Université de Bordeaux, Institut des Sciences Moléculaires, UMR \\ CNRS 5255, 351 cours de la libération, 33405 Talence, France \\ Email: \\ Brigitte Bibal ${ }^{*}$ - brigitte.bibal@u-bordeaux.fr \\ * Corresponding author \\ Keywords: \\ coordination macrocycle; homogeneous catalysis; prochiral; silver \\ Beilstein J. Org. Chem. 2019, 15, 2465-2472. \\ doi:10.3762/bjoc. 15.239 \\ Received: 06 May 2019 \\ Accepted: 20 September 2019 \\ Published: 17 October 2019 \\ Associate Editor: M. Rueping \\ (C) 2019 Cao et al.; licensee Beilstein-Institut. \\ License and terms: see end of document.
} complex; thioether ligand

\begin{abstract}
The bis-ortho-thioether 9,10-bis[(o-methylthio)phenyl]anthracene was synthesized as a syn-atropisomer, as revealed by X-ray diffraction. This alkylaryl thioether ligand (L) formed different macrocyclic complexes by coordination with silver(I) salts depending on the nature of the anion: $\mathrm{M}_{2} \mathrm{~L}_{2}$ for AgOTf and AgOTFA, $\mathrm{M}_{6} \mathrm{~L}_{4}$ for $\mathrm{AgNO}_{3}$. A discrete $\mathrm{M}_{2} \mathrm{~L}$ complex was obtained in the presence of bulky $\mathrm{PPh}_{3} \mathrm{AgOTf}$. These silver(I) complexes adopted similar structures in solution and in the solid state. As each sulfur atom in the ligand is prochiral, macrocycles $\mathrm{L}_{2} \mathrm{M}_{2}$ were obtained as mixtures of diastereoisomers, depending on the configurations of the sulfur atoms coordinated to silver cations. The X-ray structures of the two $\mathrm{L}_{2} \cdot(\mathrm{AgOTf})_{2}$ stereoisomers highlighted their different geometry. The catalytic activity of all silver(I) complexes was effective under homogeneous conditions in two tandem addition/cycloisomerization of alkynes using $0.5-1 \mathrm{~mol} \%$ of catalytic loading.
\end{abstract}

\section{Introduction}

Since the early advances in the late eighties [1-10], silver(I) catalysis has been widely exploited based on the versatile redox and soft Lewis acid properties of this coinage metal cation. Silver catalysis has proved its effectiveness for numerous transformations involving unsaturated bond activation (allene, alkyne, alkene) [11-17], radical-based reactions [18-20] and several applications in asymmetric reactions [21,22].

This successful chemistry was usually conducted in the presence of commercially available inexpensive salts (AgOTf, $\mathrm{AgNO}_{3}$ ) and eventually a (chiral) ligand. Such silver(I) com- plexes were prepared by using (bi)pyridine [19,23-26], phosphine [22,27-30], ditopic N/P [22] ligands and a few S/P and $\mathrm{S} / \mathrm{N}$ ones [31-34]. None of the silver(I) catalysts based on sulfur ligands were reported so far, although alkyl thioethers are soft $\sigma$-donor ligands such as crown thioethers that were largely developed as macrocyclic ligands for silver(I) [35-43]. Interestingly, depending on their design, these known silver(I) complexes can be discrete species [35-38], coordination driven supramolecules $[35,42]$ or coordination polymers $[39,40,42]$. To the best of our knowledge, silver crown thioether complexes were never reported as catalysts. 
Recently, we described a flexible bis-dialkyl thioether ligand for gold(III) chloride whose photoreduction to gold(I) was fast and controlled $[44,45]$. These gold complexes at different oxidation states showed efficient catalytic properties, that were highlighted in a one-pot cascade synthesis of $4 H$-benzoquinolizin-4-one. Now, we propose to investigate a rigid bis-alkylaryl thioether ligand to control the directionality and spatial orientation of its coordination to silver(I). Besides, 9,10-diphenylanthracenes (DPA) with ortho-substituted 9- and 10-aryl groups can exist as syn- or anti-atropisomers whose rotational barrier [46,47] ranges from 21 (ortho-H) to $25-29 \mathrm{kcal} / \mathrm{mol}$ (ortho$\mathrm{CH}_{3}$ ). A few ortho-substituted DPA atropisomers have been described as potent molecular switches [48,49], building-blocks for self-assembled capsules [50,51] or optical materials [52-54]. However, due to their partially frozen structure, syn-isomers of DPA are ideal candidates for directional metal coordination. Herein, a new syn-atropisomer of 9,10-DPA ortho-substituted by two thioethers is exploited as a ligand for silver(I) salts. The impact of this bis-thioether ligand on silver(I) homogeneous catalysis is evaluated in two tandem addition/cycloisomerization reactions of alkynes.

\section{Results and Discussion Synthesis of silver(I) complexes}

Ligand 1 was synthesized in one step, from commercially available 9,10-dibromoanthracene and 2-(methylthio)phenylboronic acid, using a Suzuki-Miyaura cross-coupling reaction. Notably, the yield was low (26\%) [55], and the X-ray analysis of monocrystals revealed the syn-conformation of $\mathbf{1}$ (Scheme 1). A variable temperature ${ }^{1} \mathrm{H}$ NMR (VT-NMR, Figures S10-12 in Supporting Information File 1) experiment conducted on syn-1 in the range of -30 to $110{ }^{\circ} \mathrm{C}$ in $\mathrm{C}_{2} \mathrm{D}_{2} \mathrm{Cl}_{4}$ showed the broadening of proton signals, due to the restricted rotation of the 9,10-aryl substituents in respect to the anthracene core, without any indication of a syn-to-anti isomerization.

Four silver(I) complexes 1a-d were prepared in excellent yield (77-92\%) by mixing the ligand and the following silver salts in a 1:1 ratio in dichloromethane at room temperature:
AgOTf for 1a, AgOTFA for $\mathbf{1 b}, \mathrm{AgNO}_{3}$ for $\mathbf{1 c}$ and $\mathrm{PPh}_{3} \mathrm{AgOTf}$ for $1 d$.

\section{Crystallographic structures of silver complexes}

Single crystals of 1a, 1c and 1d suitable for X-ray diffraction analysis were grown from the slow diffusion of hexane into a solution of each complex in dichloromethane. Interestingly, each prochiral sulfur atom of the ligand becomes asymmetric by coordination to silver(I). In absence of any chiral source, the complexes were obtained either as nonchiral coordination products with a center or an axis of symmetry (1a and 1c, with $(R, S) \mathbf{- 1}$ ligands) or as a racemic mixture $(\mathbf{1 d}$, with $(R, R)-\mathbf{1}$ or $(S, S)-\mathbf{1}$ ligands).

The X-ray diffraction of monocrystals 1 a revealed the formation of $(R, S-\mathbf{1})_{2} \cdot(\operatorname{AgOTf})_{2}$ macrocycles driven by silver(I) coordination (Figure 1). The two ligands are facing through the coordination of one syn-thioether group to the same silver cation. Two different crystals were isolated and highlighted the two possible arrangements of the ligands that led to different diastereoisomeric macrocycles (Figure 1a,b). In Figure 1a, each silver cation was coordinated to two sulfur atoms with the same configuration (named head-to-head coordination mode for ligands) meanwhile in Figure $1 \mathrm{~b}$, each $\mathrm{Ag}(\mathrm{I})$ cation was coordinated to two sulfur atoms with $(R)$ - and $(S)$-configuration, respectively (head-to-tail ligand coordination mode). These diastereoisomeric crystals presented a slightly different spatial arrangement.

The head-to head macrocycle 1a had a parallelepiped shape (Figure 1a): the interplanar distance between two anthracenes was ca. $6.31 \AA$ and the dihedral angle between the anthracene core and its 9,10 -aryl substituents was $89^{\circ}$ and $104^{\circ}$, respectively. The head-to-tail macrocycle 1a adopted a V-shape (Figure 1b): the angle between the planes of the two anthracenes was $73.2^{\circ}$ and the dihedral angles between the aryl substituents and the anthracene plane ranged between $77^{\circ}$ and $87^{\circ}$, respectively.

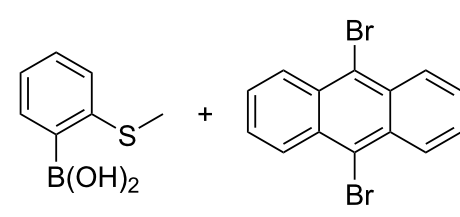

$\underset{\text { toluene } / \mathrm{EtOH} / \mathrm{H}_{2} \mathrm{O}}{\mathrm{Pd}\left(\mathrm{PPh}_{3}\right)_{4}, \mathrm{~K}_{2} \mathrm{CO}_{3}}$
$110^{\circ} \mathrm{C}, 24 \mathrm{~h}$

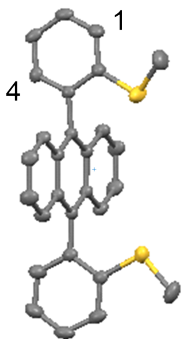



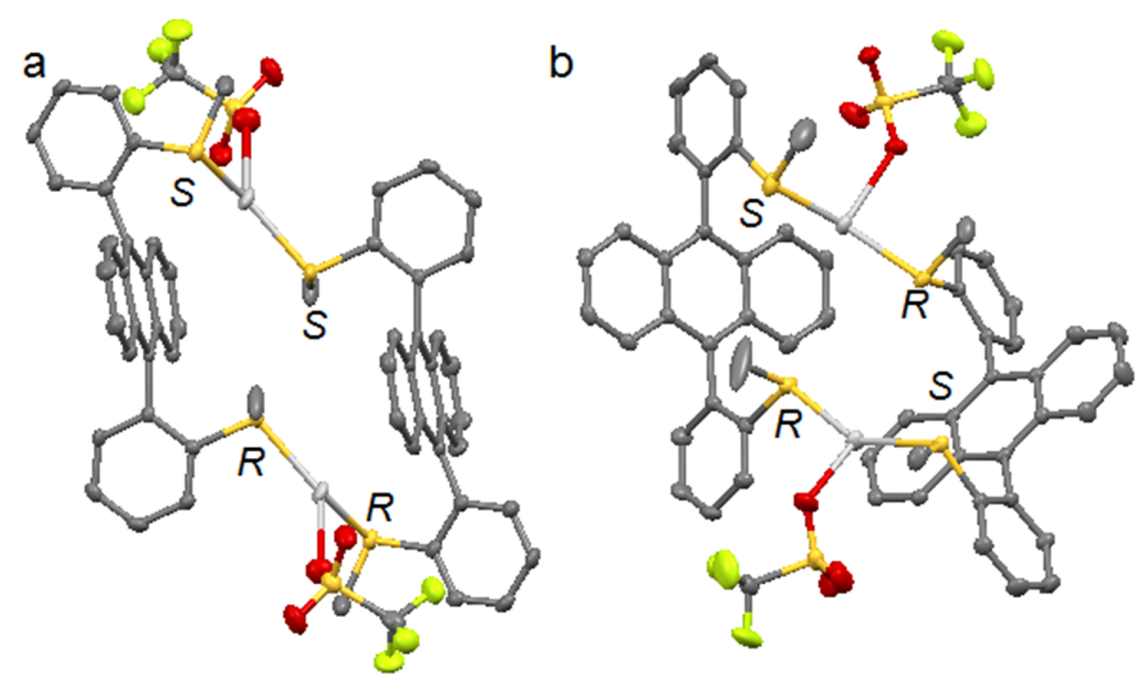

Figure 1: X-ray structures of complex 1a, as two diastereoisomeric macrocycles $(R, S-1)_{2} \cdot(\text { AgOTf })_{2}$ with ligands assembled in: (a) a head-to-head fashion and, (b) a head-to-tail mode. Hydrogen atoms are omitted for clarity.

In solution, the two diastereoisomeric macrocycles coexisted, possibly in different ratios as the chemical shift of protons on the 9,10-phenyl and anthracene moieties were found slightly different for three different batches of silver complexes prepared by the same procedure (see Supporting Information File 1, Figure S9).

The complex formed with $\mathrm{AgNO}_{3}$ had a different stoichiometry, due to the multidentate nitrate anions. The X-ray structure of 1c appeared as a large $(R, S-\mathbf{1})_{4} \cdot\left(\mathrm{AgNO}_{3}\right)_{6}$ complex with three nitrate anions as coordinating bridges between the two symmetric $\mathrm{M}_{3} \mathrm{~L}_{2}$ units (Figure 2). The resulting coordinated macrocycle $\mathrm{M}_{6} \mathrm{~L}_{4}$ had a globular shape that displayed the polyaromatic ligands towards the exterior and fully encapsulated two nitrate anions and the silver(I) cations. This silver nitrate complex was thus soluble in chlorinated solvents.

In the presence of the bulky triphenylphosphine silver triflate salt, a monocoordination occurred between $\mathrm{Ag}(\mathrm{I})$ and each sulfur atom of ligand 1 leading to a discrete complex (syn1) $\cdot\left(\mathrm{Ph}_{3} \mathrm{PAgOTf}\right)_{2}$, as revealed by ${ }^{1} \mathrm{H}$ NMR and $\mathrm{X}$-ray (Figure 3). The steric hindrance also induced the access to a racemic mixture of $(R, R)$ - and $(S, S)$-complexes where triphenylphosphine groups were located at the opposite sides of the anthracene core.

The crystallographic structures of $\mathbf{1 a}, \mathbf{1 c}$ and $\mathbf{1 d}$ showed that both ligand syn-1 and the nature of silver anion impacted on the stoichiometry of coordination complexes. Atropisomer $\mathbf{1}$ directed the self-assembly towards the same half-space (regarding the anthracene core). The triflate anion lead to a $[2+2]$ macrocycle meanwhile the more coordinating nitrate

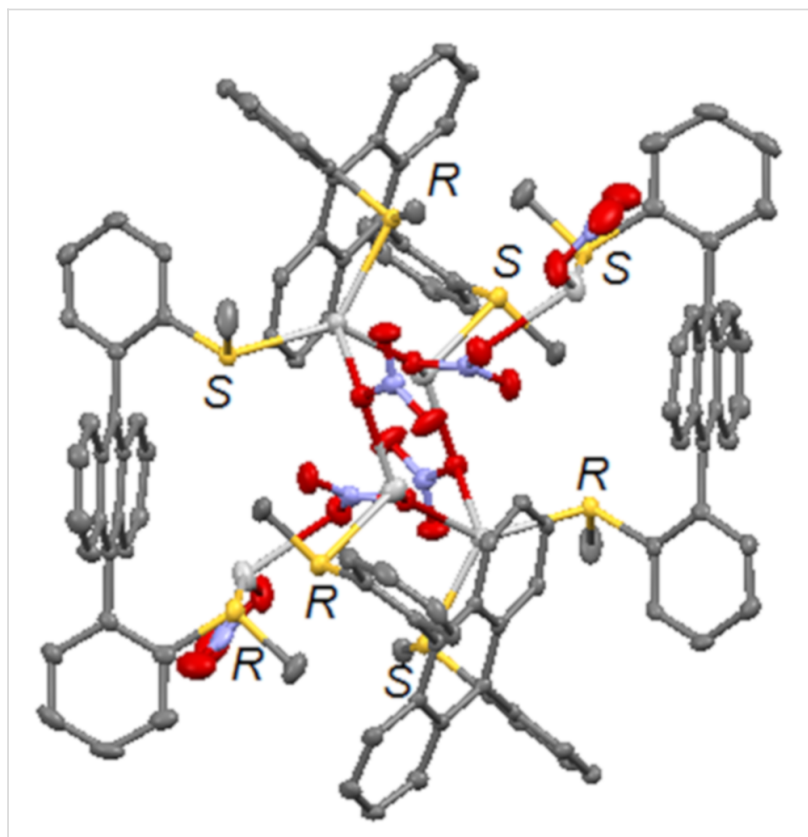

Figure 2: X-ray structure of complex $1 \mathrm{c}$, as a $(R, S-1)_{4} \cdot\left(\mathrm{AgNO}_{3}\right)_{6}$ cage with three nitrate anions as coordinating bridges. Hydrogen atoms are omitted for clarity.

anion induced the formation of a large globular macrocycle $\mathrm{M}_{6} \mathrm{~L}_{4}$. A bulkier silver salt favored a mono-coordination on each binding site.

\section{Silver(I) complexes in solution}

Surprisingly, several batches of each complex 1a-d were compared by ${ }^{1} \mathrm{H}$ NMR $\left(\mathrm{CDCl}_{3}, 2 \mathrm{mM}\right.$ ) (see Supporting Information File 1, Figure S9) and revealed slight variations in the chemical shifts that might originate from the presence of several 


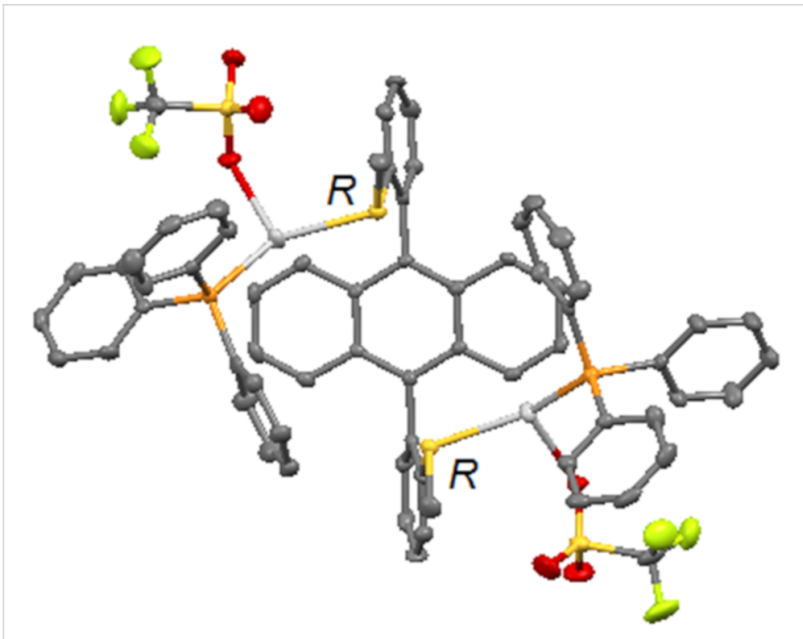

Figure 3: X-ray structure of complex $1 \mathrm{~d}$, as a racemic mixture of $(R, R)$ - and $(S, S)-(s y n-1) \cdot\left(\mathrm{PPh}_{3} \mathrm{AgOTf}\right)_{2}$.

species in solution, such as self-aggregates, mixture of conformers, mixture of diastereoisomers or complexes with different stoichiometry.

To investigate the possible self-aggregation of complexes 1a-c (7 mM), VT NMR experiments were conducted between $-30{ }^{\circ} \mathrm{C}$ and $60{ }^{\circ} \mathrm{C}$ in $\mathrm{CDCl}_{3}$. For complex 1a, the aromatic protons were shifted for 0.1 to $0.2 \mathrm{ppm}$ meanwhile the methyl of the thioether group was shifted for $0.12 \mathrm{ppm}$ (Figure 4). The two most affected aromatic protons were located on the 9,10substituents, the one adjacent to SMe group (H1) and the one closest to the anthracene core (H4). Similar changes on VT NMR were observed for complex $\mathbf{1 b}$ and $\mathbf{1 c}$ (see Supporting Information File 1, Figures S11 and 12), with chemical shift variations in the range of 0.1 to $0.3 \mathrm{ppm}$ for $1 \mathrm{c}$. The little differ- ences observed on ${ }^{1} \mathrm{H}$ NMR spectra at $60{ }^{\circ} \mathrm{C}$ accounted for a slight change in the geometry of the complexes probably due to the thermal motion, and not to the dissociation of self-aggregates. In the temperature range of -30 to $60{ }^{\circ} \mathrm{C}$, none dissociated free ligand was observed, thus confirming that coordinated macrocycles 1a-c were thermally stable. At room temperature, the slight different ${ }^{1} \mathrm{H}$ NMR spectra may account for the existence of several conformations for these constrained coordinated architectures, which still have a certain degree of freedom, that is required for further catalytic properties.

Diffusion-ordered spectroscopy (DOSY) ${ }^{1} \mathrm{H}$ NMR was also used on complexes 1a-d $(5 \mathrm{mM})$ in $\mathrm{CDCl}_{3}$ (Supporting Information File 1, Table S7). Each complex appeared as a unique species whose diffusion coefficient $(D)$ can be fitted. So the presence of species with different coordination modes can be excluded. Unexpectedly, the diffusion constants of both complexes $\mathbf{1 a}$ and $\mathbf{1 b}$ were disparate $\left(0.6-1.9 \times 10^{-9} \mathrm{~m}^{2} / \mathrm{s}\right)$ depending on the batches meanwhile the $D$ values of complexes $1 \mathbf{c}$ and $1 \mathrm{~d}$ at $5 \mathrm{mM}$ were similar $\left(0.80-0.93 \times 10^{-9} \mathrm{~m}^{2} / \mathrm{s}\right)$ and not depending on the batch. The nonreproducibility of DOSY experiments for $\mathbf{1 a}$ and $\mathbf{1 b}$ might originate from the uncontrolled formation of different diastereoisomers by coordination which had different geometries. Thereafter, the silver(I) complexes are discussed with the proposed stoichiometry from $\mathrm{X}$-ray and NMR data, without accounting for stereochemistry: $\mathrm{M}_{2} \mathrm{~L}_{2}$ for AgOTf and AgOTFA complexes (1a,b), $\mathrm{M}_{6} \mathrm{~L}_{4}$ for $\mathrm{AgNO}_{3}$ one (1c) and $\mathrm{M}_{2} \mathrm{~L}$ complex with $\mathrm{PPh}_{3} \mathrm{AgOTf}$ (1d).

Finally, the photophysical properties of ligand syn-1 $(20 \mu \mathrm{M})$ and complexes 1a-d $(30 \mu \mathrm{M})$ were evaluated in dichloromethane (Supporting Information File 1, Figures S4-S8). The $\mathrm{UV}-\mathrm{visible}$ and fluorescence emission spectra $\left(\lambda_{\mathrm{exc}}=345 \mathrm{~nm}\right)$

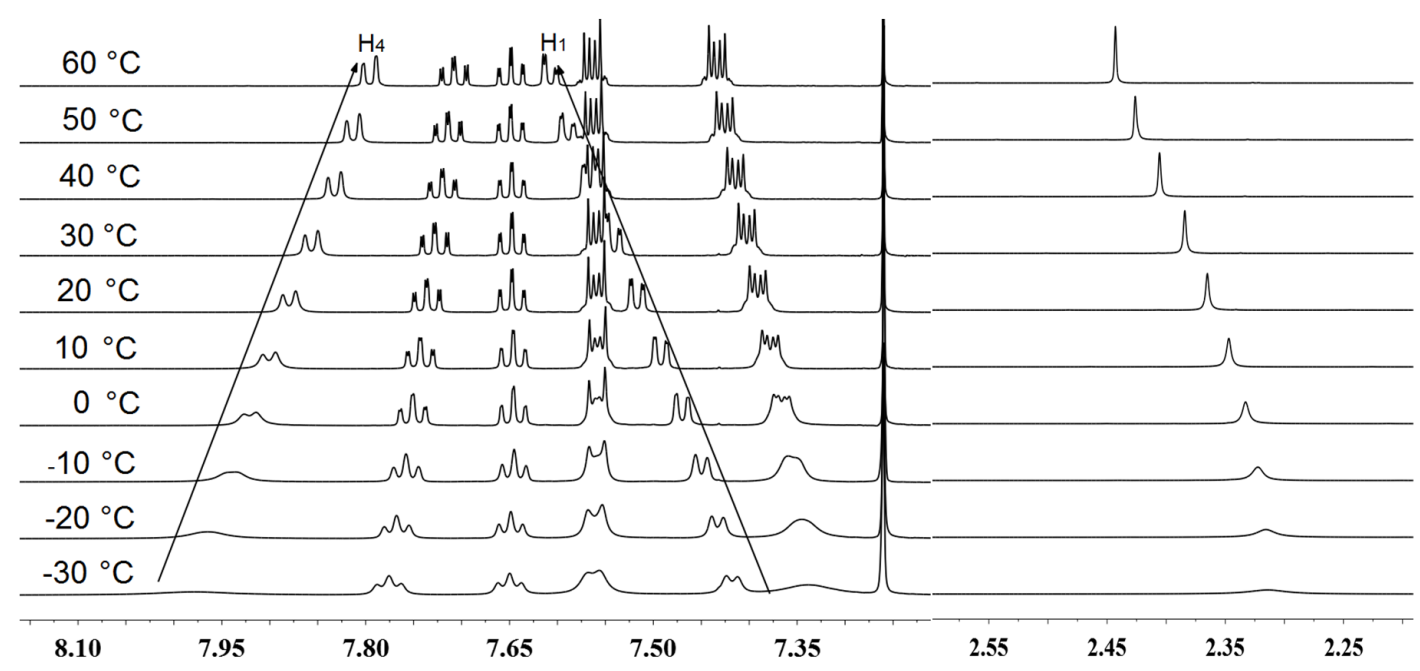

Figure 4: Variable temperature ${ }^{1} \mathrm{H}$ NMR of complex $1 \mathrm{a}$ in $\mathrm{CDCl}_{3}(7 \mathrm{mM})$ from $-30{ }^{\circ} \mathrm{C}$ to $60{ }^{\circ} \mathrm{C}$. 
of ligand and complexes were similar and correspond to those of 9,10-diphenylanthracene [56,57]. The silver(I) coordination on the ligand and the formation of supramolecular systems does not seem to affect the spectroscopic properties of the 9,10diphenylanthracene system.

\section{Silver catalysis}

As silver(I) salts exhibit a high alkynophilicity [11-17], the new complexes 1a-d were evaluated as homogeneous catalysts in two tandem addition/cycloisomerization reactions using alkynes $\mathbf{2}$ and $\mathbf{3}$.

2-Alkynylbenzaldehyde 2 [58,59] was chosen as the first model substrate for a cyclization reaction in the presence of methanol as a second nucleophile. This tandem addition/cycloisomerization was previously described in high yields $(>95 \%)$ using 5 mol \% catalyst loadings starting from 2-(alkynyl)quinoline-3carbaldehyde $[60,61]$ with AgOTf catalyst and starting from 2-alkynylbenzaldehyde derivatives [62] in the presence of a macrocyclic pyridine-tetraaza complex of $\mathrm{Ag}(\mathrm{I})$ as a catalyst. In our control experiment, alkyne $\mathbf{2}$ was converted into product $\mathbf{4}$ in high yield (88\%) using AgOTf at 5 mol \% (Table 1, entry 1). Interestingly, 1-methoxyisochromene $\mathbf{4}$ can also be isolated in $89 \%$ yield, using a AgOTf catalytic loading of $1 \mathrm{~mol} \%$ (Table 1, entry 2). All silver complexes 1a-d (1 mol \%) efficiently catalyzed the intramolecular cyclization with $65-92 \%$ yields (Table 1, entries 3-7). To our delight, the transformation also reached $92 \%$ yield by employing $\mathbf{1 a}$ at $0.5 \mathrm{~mol} \%$ (Table 1 , entry 4). Compared to literature [60-62], catalyst 1a is effective for the tandem cyclization of 2-alkynylbenzaldehyde $\mathbf{2}$ at lower

Table 1: Addition/cycloisomerization of alkyne $2 .^{a}$<smiles>O=Cc1ccccc1C#Cc1ccccc1</smiles>

2

\begin{tabular}{llll}
\hline Entry & [Ag] catalyst & Loading (mol \%) & Yield $^{\mathrm{b}}(\%)$ \\
\hline 1 & AgOTf & 5 & 88 \\
2 & AgOTf & 1 & 89 \\
3 & 1a & 1 & 92 \\
4 & 1a & 0.5 & 92 \\
5 & 1b & 1 & 73 \\
6 & 1c & 1 & 85 \\
7 & 1d & 1 & 65 \\
\hline
\end{tabular}

aUnless specified, all the reactions were carried out in dry $\mathrm{CH}_{2} \mathrm{Cl}_{2}$ at room temperature for $12-16 \mathrm{~h}$ with alkyne $2(30 \mathrm{mg}, 0.15 \mathrm{mmol})$, $\mathrm{MeOH}(0.45 \mathrm{mmol})$ and a silver $(\mathrm{l})$ catalyst $(0.5-5 \mathrm{~mol} \%)$. blsolated yield. $\underset{\mathrm{CH}_{2} \mathrm{Cl}_{2}, \mathrm{rt}}{[\mathrm{Ag}], \mathrm{MeOH}}$

4

catalyst loadings and under milder conditions $\left(20^{\circ} \mathrm{C}\right.$, full conversion after $12 \mathrm{~h}$ ). As previously observed for inorganic $\mathrm{Ag}$ salts [60], the catalyst efficiency for this cyclization slightly depends on its anion nature $(\mathbf{1 a}>\mathbf{1 c}>\mathbf{1 b}>\mathbf{1 d})$.

To further demonstrate the catalytic properties of silver(I) complexes 1a-d, we investigated their performance in the cyclization [63] of alkynone 3 [63-65] in the presence of benzylamine, as a nucleophile (Table 2) that lead to substituted pyrrole $\mathbf{5}$. This tandem condensation/cycloisomerization was previously reported in $78 \%$ yield using AgOTf at $5 \mathrm{~mol} \%$ (reaction time $3.5 \mathrm{~h}, 50{ }^{\circ} \mathrm{C}$ ) [63]. Noteworthy, at $50{ }^{\circ} \mathrm{C}$ the transformation occurs in $35 \%$ yield without any catalyst (Table 2 , entry 1 ). In our hands, using AgOTf (2.5 mol \%), the product was obtained in $73 \%$ yield meanwhile $67-76 \%$ yield were reached when silver complexes 1a-d at $1 \mathrm{~mol} \%$ were employed (Table 2, entries 2-6). Interestingly, a lower catalytic loading of $0.5 \mathrm{~mol} \%$ allowed the isolation of $73 \%$ of pyrrole 5 in the presence of catalysts $\mathbf{1 a}$ and $\mathbf{1 b}$ (Table 2, entries 7 and 8). Under the same conditions, the catalytic efficiency of $\mathbf{1 c}$ and $\mathbf{1 d}$ was slightly lower (64-67\% yield) but similar to AgOTf at $2.5 \mathrm{~mol} \%$ (Table 2, entries 9 and 10). For this second tandem model cyclization, the effect of the anion on the catalysts' efficiency was weak. Finally, this second model addition/cycloisomerization was successfully catalyzed by silver complexes 1a-b also at lower loadings $(0.5 \mathrm{~mol} \%)$ than AgOTf.

Table 2: Condensation/cycloisomerization of alkyne $3^{\text {a }}$<smiles>C#CCC1CCCCC1=O</smiles>

3

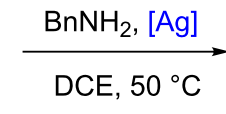

\begin{tabular}{llll}
\hline Entry & [Ag] catalyst & Loading (mol \%) & Yield $(\%)$ \\
\hline 1 & - & - & 35 \\
2 & AgOTf & 2.5 & 73 \\
3 & 1a & 1 & 76 \\
4 & 1b & 1 & 67 \\
5 & 1c & 1 & 72 \\
6 & 1d & 1 & 76 \\
7 & 1a & 0.5 & 73 \\
8 & 1b & 0.5 & 73 \\
9 & 1c & 0.5 & 67 \\
10 & 1d & 0.5 & 64 \\
\hline
\end{tabular}

aUnless specified, all the reactions were performed at $50{ }^{\circ} \mathrm{C}$ under argon atmosphere in dry 1,2-dichloroethane for 12-16 h, in the presence of alkyne $3(27 \mathrm{mg}, 0.2 \mathrm{mmol})$, benzylamine $(0.3 \mathrm{mmol})$ and a silver(I) catalyst $(0.5-2.5 \mathrm{~mol} \%)$. ' Isolated yield. 


\section{Conclusion}

9,10-Diphenylanthracene with two ortho-substituted thioether functional groups is an attractive scaffold which allowed us to design and prepare a stable $s y n$-atropisomer ligand $\mathbf{1}$ which can direct coordinate towards the same half-space. Three macrocyclic silver complexes were then synthesized and their coordination modes revealed by $\mathrm{X}$-ray diffraction were depended on the nature of the anion, i.e., $\mathrm{M}_{2} \mathrm{~L}_{2}$ for ${ }^{-} \mathrm{OTf} /{ }^{-} \mathrm{OTFA}$ and $\mathrm{M}_{6} \mathrm{~L}_{4}$ for $\mathrm{NO}_{3}{ }^{-}$. With prochiral thioether groups, $\mathrm{M}_{2} \mathrm{~L}_{2}$ macrocycles were obtained as mixtures of diastereoisomers due to the two possible arrangements of the coordinated ligands (head-to-head or head-to-tail) resulting into different spatial arrangements. In solution, the architectures of silver(I) complexes with ligand syn-1 seemed to be similar to the solid-state structures. The silver(I) complexes were evaluated as homogeneous catalysts in two tandem addition/cycloisomerization reactions on model alkynes to give the expected cyclization products in excellent yields, also by using $0.5 \mathrm{~mol} \%$ catalytic loading, with efficiencies similar to those reported in the literature [60-63] with inorganic silver salts and complexes employed at higher loadings (2.5-5 mol \%). The use of original and effective silver complexes might be a way to lower the catalytic loading in silvercatalyzed transformations and opens perspectives to the design of new asymmetric ligands.

\section{Experimental}

General procedure for the synthesis of silver(I) complexes 1a-d: To a solution of ligand $\mathbf{1}(15 \mathrm{mg}, 0.0355 \mathrm{mmol})$ in anhydrous $\mathrm{CH}_{2} \mathrm{Cl}_{2}(1 \mathrm{~mL})$ was added the corresponding silver salt ( $0.0355 \mathrm{mmol}, 1.0$ equiv) under argon atmosphere at room temperature. The mixture was stirred for $4 \mathrm{~h}$. The clear solution was concentrated to ca. $0.3 \mathrm{~mL}$ and diethyl ether $(2.0 \mathrm{~mL})$ was slowly added to afford a precipitation. After filtration, the isolated solid was washed with diethyl ether and dried under vacuum.

\section{General procedure for the acetalization/cycloisomerization} of alkyne 2: An oven-dried Schlenk tube was charged with the silver(I) catalyst (0.5-5 mol \%), then degassed and backfilled with argon for three times. A solution of alkyne $2(30 \mathrm{mg}$, $0.15 \mathrm{mmol})$ in anhydrous $\mathrm{CH}_{2} \mathrm{Cl}_{2}(1 \mathrm{~mL})$ and dry $\mathrm{MeOH}$ $(18 \mu \mathrm{L}, 0.45 \mathrm{mmol})$ were successively added. The mixture was stirred at room temperature for $12 \mathrm{~h}$. The solution was concentrated and the crude residue was purified by column chromatography on silica gel (eluent: petrol ether/ethyl acetate 50:1) to obtain 1-methoxyisochromene 4.

General procedure for condensation/cycloisomerization of alkyne 3: A dry Schlenk tube charged with silver catalyst (0.5-2.5 mol \%) was degassed and backfilled with argon for three times. A solution of alkyne $3(27 \mathrm{mg}, 0.2 \mathrm{mmol})$ in an- hydrous $\mathrm{CH}_{2} \mathrm{Cl}_{2}(1 \mathrm{~mL})$ and benzylamine $(33 \mu \mathrm{L}, 0.3 \mathrm{mmol})$ were successively added. The mixture was stirred at $50{ }^{\circ} \mathrm{C}$ for $12 \mathrm{~h}$. The solution was concentrated under reduced pressure and the crude product was purified by column chromatography on silica gel (eluent: petrol ether/ethyl acetate 70:1) to obtain pyrrole 5.

\section{Supporting Information}

\section{Supporting Information File 1}

Synthesis and characterization data of ligand and silver complexes, details of X-ray structures.

[https://www.beilstein-journals.org/bjoc/content/ supplementary/1860-5397-15-239-S1.pdf]

\section{Supporting Information File 2}

Crystallographic structures CCDC 1883532, 1883535, 1883536, 1883538 and 1883674 of ligand $\mathbf{1}$ and silver complexes 1a-d (.cif files).

[https://www.beilstein-journals.org/bjoc/content/ supplementary/1860-5397-15-239-S2.zip]

\section{Acknowledgements}

Financial support was provided by the China Scholarship Council (Z.C. Ph.D. fellowship), the University of Bordeaux and Centre National de la Recherche Scientifique. The authors acknowledge Damien Jardel and Clotilde Davies for their contribution to the synthesis of the syn-ligand, Stéphane Massip for the resolution of the corresponding crystallographic structure.

\section{ORCID ${ }^{\circledR}$ iDs}

Cybille Rossy - https://orcid.org/0000-0003-4107-9977 Brigitte Bibal - https://orcid.org/0000-0003-0146-8396

\section{References}

1. Castellino, S.; Sims, J. J. Tetrahedron Lett. 1984, 25, 4059-4062. doi:10.1016/s0040-4039(01)90181-9

2. Lathbury, D.; Gallagher, T. Tetrahedron Lett. 1985, 26, 6249-6252. doi:10.1016/s0040-4039(00)95065-2

3. Grimaldi, J.; Cormons, A. Tetrahedron Lett. 1986, 27, 5089-5090. doi:10.1016/s0040-4039(00)85140-0

4. Pale, P.; Chuche, J. Tetrahedron Lett. 1987, 28, 6447-6448. doi:10.1016/s0040-4039(00)96884-9

5. Sawamura, M.; Hamashima, H.; Ito, Y. J. Org. Chem. 1990, 55, 5935-5936. doi:10.1021/j000311a007

6. Hayashi, T.; Uozumi, Y.; Yamazaki, A.; Sawamura, M.; Hamashima, H.; Ito, Y. Tetrahedron Lett. 1991, 32, 2799-2802. doi:10.1016/0040-4039(91)85090-r

7. Kimura, M.; Fugami, K.; Tanaka, S.; Tamaru, Y. Tetrahedron Lett. 1991, 32, 6359-6362. doi:10.1016/0040-4039(91)80169-7 
8. Marshall, J. A.; Wang, X. J. J. Org. Chem. 1991, 56, 960-969. doi:10.1021/j000003a013

9. Cooper, D. M.; Grigg, R.; Hargreaves, S.; Kennewell, P.; Redpath, J. Tetrahedron 1995, 51, 7791-7808. doi:10.1016/0040-4020(95)00397-q

10. Yanagisawa, A.; Nakashima, H.; Ishiba, A.; Yamamoto, $\mathrm{H}$. J. Am. Chem. Soc. 1996, 118, 4723-4724. doi:10.1021/ja9603315

11. Halbes-Letinois, U.; Weibel, J.-M.; Pale, P. Chem. Soc. Rev. 2007, 36, 759-769. doi:10.1039/b602151b

12. Alvarez-Corral, M.; Muñoz-Dorado, M.; Rodriguez-Garcia, I. Chem. Rev. 2008, 108, 3174-3198. doi:10.1021/cr078361l

13. Belmont, P.; Parker, E. Eur. J. Org. Chem. 2009, 6075-6089. doi:10.1002/ejoc.200900790

14. Muñoz, M. P. Chem. Soc. Rev. 2014, 43, 3164-3184. doi:10.1039/c3cs60408j

15. Fang, G.; Bi, X. Chem. Soc. Rev. 2015, 44, 8124-8173. doi:10.1039/c5cs00027k

16. Blanc, A.; Bénéteau, V.; Weibel, J.-M.; Pale, P. Org. Biomol. Chem. 2016, 14, 9184-9205. doi:10.1039/c6ob01468b

17. Sekine, K.; Yamada, T. Chem. Soc. Rev. 2016, 45, 4524-4532. doi:10.1039/c5cs00895f

18. Zheng, Q.-Z.; Jiao, N. Chem. Soc. Rev. 2016, 45, 4590-4627. doi: $10.1039 / \mathrm{c} 6 \mathrm{cs} 00107 \mathrm{f}$

19. Alderson, J. M.; Corbin, J. R.; Schomaker, J. M. Acc. Chem. Res. 2017, 50, 2147-2158. doi:10.1021/acs.accounts.7b00178

20. Fang, G.; Cong, X.; Zanoni, G.; Liu, Q.; Bi, X. Adv. Synth. Catal. 2017, 359, 1422-1502. doi:10.1002/adsc.201601179

21. Naodovic, M.; Yamamoto, H. Chem. Rev. 2008, 108, 3132-3148. doi:10.1021/cr068413r

22. Pellissier, H. Chem. Rev. 2016, 116, 14868-14917. doi:10.1021/acs.chemrev.6b00639

23. Türkmen, Y. E.; Montavon, T. J.; Kozmin, S. A.; Rawal, V. H. J. Am. Chem. Soc. 2012, 134, 9062-9065. doi:10.1021/ja302537j

24. Zeng, Y.; Zhang, L.; Zhao, Y.; Ni, C.; Zhao, J.; Hu, J. J. Am. Chem. Soc. 2013, 135, 2955-2958. doi:10.1021/ja312711c

25. Zeng, Y.; Hu, J. Chem. - Eur. J. 2014, 20, 6866-6870. doi:10.1002/chem.201402846

26. Tseberlidis, G.; Dell'Acqua, M.; Valcarenghi, D.; Gallo, E.; Rossi, E.; Abbiati, G.; Caselli, A. RSC Adv. 2016, 6, 97404-97419. doi:10.1039/c6ra22231e

27. Ji, J.-X.; Au-Yeung, T. T.-L.; Wu, J.; Yip, C. W.; Chan, A. S. C. Adv. Synth. Catal. 2004, 346, 42-44. doi:10.1002/adsc.200303148

28. Yao, X.; Li, C.-J. Org. Lett. 2005, 7, 4395-4398. doi:10.1021/ol051575+

29. Takechi, S.; Yasuda, S.; Kumagai, N.; Shibasaki, M. Angew. Chem., Int. Ed. 2012, 51, 4218-4222. doi:10.1002/anie.201200520

30. Su, Y.; Lu, M.; Dong, B.; Chen, H.; Shi, X. Adv. Synth. Catal. 2014, 356, 692-696. doi:10.1002/adsc.201300785

31. Chen, Q.-A.; Zeng, W.; Wang, D.-W.; Zhou, Y.-G. Synlett 2009, 2236-2241. doi:10.1055/s-0029-1217805

32. Iglesias-Sigüenza, J.; Ros, A.; Díez, E.; Magriz, A.; Vázquez, A.; Álvarez, E.; Fernández, R.; Lassaletta, J. M. Dalton Trans. 2009, 8485-8488. doi:10.1039/b910846g

33. Prakash, O.; Joshi, H.; Kumar, U.; Sharma, A. K.; Singh, A. K. Dalton Trans. 2015, 44, 1962-1968. doi:10.1039/c4dt02813a

34. Rasheed, O. K.; Bawn, C.; Davies, D.; Raftery, J.; Vitorica-Yrzebal, I.; Pritchard, R.; Zhou, H.; Quayle, P. Eur. J. Org. Chem. 2017, 5252-5261. doi:10.1002/ejoc.201701033
35. Küppers, H.-J.; Wieghardt, K.; Tsay, Y.-H.; Krüger, C.; Nuber, B.; Weiss, J. Angew. Chem., Int. Ed. Engl. 1987, 26, 575-576. doi:10.1002/anie.198705751

36. De Groot, B.; Jenkins, H. A.; Loeb, S. J. Inorg. Chem. 1992, 31 , 203-208. doi:10.1021/ic00028a015

37. Blake, A. J.; Gould, R. O.; Parsons, S.; Radek, C.; Schröder, M. Angew. Chem., Int. Ed. Engl. 1995, 34, 2374-2376. doi:10.1002/anie.199523741

38. Alberto, R.; Nef, W.; Smith, A.; Kaden, T. A.; Neuburger, M.; Zehnder, M.; Frey, A.; Abram, U.; Schubiger, P. A. Inorg. Chem. 1996, 35, 3420-3427. doi:10.1021/ic951421y

39. Blake, A. J.; Li, W.-S.; Lippolis, V.; Schröder, M. Chem. Commun. 1997, 1943-1944.

40. Alberto, R.; Angst, D.; Schubiger, A. P.; Abram, U.; Ortner, K.; Kaden, T. A. Chem. Commun. 1999, 1513-1514. doi:10.1039/a903455b

41. Blake, A. J.; Champness, N. R.; Howdle, S. M.; Webb, P. B. Inorg. Chem. 2000, 39, 1035-1038. doi:10.1021/ic991145d

42. Casula, A.; Nairi, V.; Fernández-Moreira, V.; Laguna, A.; Lippolis, V.; Garau, A.; Gimeno, M. C. Dalton Trans. 2015, 44, 18506-18517. doi:10.1039/c5dt02723c

43. Chang, Y.-P.; Levason, W.; Reid, G. Dalton Trans. 2016, 45 , 18393-18416. doi:10.1039/c6dt03409h

44. Mongin, C.; Pianet, I.; Jonusauskas, G.; Bassani, D. M.; Bibal, B. ACS Catal. 2015, 5, 380-387. doi:10.1021/cs5016063

45. Cao, Z.; Bassani, D. M.; Bibal, B. Chem. - Eur. J. 2018, 24 , 18779-18787. doi:10.1002/chem.201804322

46. Nikitin, K.; Müller-Bunz, H.; Ortin, Y.; Muldoon, J.; McGlinchey, M. J. Org. Lett. 2011, 13, 256-259. doi:10.1021/ol102665y

47. Marriott, P. J.; Lai, Y.-H. J. Chromatogr. A 1998, 447, 29-41. doi:10.1016/0021-9673(88)90004-0

48. Zehm, D.; Fudickar, W.; Linker, T. Angew. Chem., Int. Ed. 2007, 46, 7689-7692. doi:10.1002/anie.200700443

49. Zehm, D.; Fudickar, W.; Hans, M.; Schilde, U.; Kelling, A.; Linker, T. Chem. - Eur. J. 2008, 14, 11429-11441. doi:10.1002/chem.200801355

50. Suzuki, A.; Kondo, K.; Akita, M.; Yoshizawa, M. Angew. Chem., Int. Ed. 2013, 52, 8120-8123. doi:10.1002/anie.201302789

51. Yazaki, K.; Akita, M.; Prusty, S.; Chand, D. K.; Kikushi, T.; Sato, H.; Yoshizawa, M. Nat. Commun. 2017, 8, 15914-15921. doi:10.1038/ncomms 15914

52. lida, A.; Yamaguchi, S. Chem. Commun. 2009, 3002-3004. doi:10.1039/b901794a

53. Moon, H.; Jun, Y. W.; Kim, D.; Ryu, H. G.; Wang, T.; Kim, K. H.; Huh, Y.; Jung, J.; Ahn, K. H. Chem. - Asian J. 2016, 11, 2518-2523. doi:10.1002/asia.201600986

54. Belyaev, A.; Chen, Y.-T.; Su, S.-H.; Tseng, Y.-J.; Karttunen, A. J.; Tunik, S. P.; Chou, P.-T.; Koshevoy, I. O. Chem. Commun. 2017, 53, 10954-10957. doi:10.1039/c7cc06882d

55. Du, C.; Ye, S.; Liu, Y.; Guo, Y.; Wu, T.; Liu, H.; Zheng, J.; Cheng, C.; Zhu, M.; Yu, G. Chem. Commun. 2010, 46, 8573-8575. doi:10.1039/c0cc04147e

56. Meech, S. R.; Phillips, D. J. Photochem. 1983, 23, 193-217. doi:10.1016/0047-2670(83)80061-6

57. Suzuki, K.; Kobayashi, A.; Kaneko, S.; Takehira, K.; Yoshihara, T.; Ishida, H.; Shiina, Y.; Oishi, S.; Tobita, S. Phys. Chem. Chem. Phys. 2009, 11, 9850-9860. doi:10.1039/b912178a

58. Sakamoto, T.; Kondo, Y.; Miura, N.; Hayashi, K.; Yamanaka, H. Heterocycles 1986, 24, 2311-2314. doi:10.3987/r-1986-08-2311 
59. Dyker, G.; Stirner, W.; Henkel, G. Eur. J. Org. Chem. 2000, 1433-1441.

doi:10.1002/(sici)1099-0690(200004)2000:8<1433::aid-ejoc1433>3.0.c o;2-7

60. Godet, T.; Vaxelaire, C.; Michel, C.; Milet, A.; Belmont, P. Chem. - Eur. J. 2007, 13, 5632-5641. doi:10.1002/chem.200700202

61. Parker, E.; Leconte, N.; Godet, T.; Belmont, P. Chem. Commun. 2011, 47, 343-345. doi:10.1039/c0cc02623a

62. Dell'Acqua, M.; Castano, B.; Cecchini, C.; Pedrazzini, T.; Pirovano, V.; Rossi, E.; Caselli, A.; Abbiati, G. J. Org. Chem. 2014, 79, 3494-3505. doi:10.1021/j05002559

63. Harrison, T. J.; Kozak, J. A.; Corbella-Pané, M.; Dake, G. R. J. Org. Chem. 2006, 71, 4525-4529. doi:10.1021/jo060382c

64. Trost, B. M.; Rudd, M. T. J. Am. Chem. Soc. 2005, 127, 4763-4776. doi:10.1021/ja043097o

65. Jazkewitsch, O.; Mondrzyk, A.; Staffel, R.; Ritter, H. Macromolecules 2011, 44, 1365-1371. doi:10.1021/ma1027627

\section{License and Terms}

This is an Open Access article under the terms of the Creative Commons Attribution License (http://creativecommons.org/licenses/by/4.0). Please note that the reuse, redistribution and reproduction in particular requires that the authors and source are credited.

The license is subject to the Beilstein Journal of Organic Chemistry terms and conditions: (https://www.beilstein-journals.org/bjoc)

The definitive version of this article is the electronic one which can be found at: doi:10.3762/bjoc.15.239 